\title{
A Study on Education Idea of the Specialized Higher Technical Institute during the New Period
}

\author{
Si-Jin Tian, Peng Zhu, Dao-Liang Zhao, Zhang-Rui Liu, Jia-Hua Li \\ School of Urban Construction \& Safety Engineering \\ Shanghai Institute of Technology, Shanghai 201418, China \\ tiansijin@126.com
}

Keywords: Education, Student exchange, Practice training, Record certification.

\begin{abstract}
Higher education is becoming one of the most important needs for mankind. The main education system in the world is academic universities, similar institutions of high education and the specialized higher technical college or polytechnic institute. Nearly every fourth new student enrolls today at a polytechnic institute. Therefore, it is necessary to discuss and study the education idea and education model for those institutes and students. Through the statistics of the Chinese tech-hours, this article considers that the Chinese students in polytechnic institute have too less tech-hours for practice to train technical skills. And meantime, the student numbers and laboratory numbers have not reached a common ratio. To solve the above problems, one of the effective methods is to use the resources of society, including offices, enterprises and factories etc. According to the analysis of the studying record, this article puts forward a proposal that the report card should be reformed. Especially, the practical report list should include more details instead of today only one number.
\end{abstract}

\section{Introduction}

We are today in the stage of Education for an information age. With the development of society, higher education is becoming one of the most important needs for the people. The main education system in the world is academic universities, similar institutions of high education and the specialized higher technical college or polytechnic institutes. Nearly every fourth new student enrolls today at a polytechnic institute. But the education model for this type of institute has not matured in some countries and areas.

The Chinese ancient educator and thinker Mengzi said in his Mensius[1] "there is a city with an inner wall of three li (one li $=0.5$ kilometer) circumference and an outer wall of seven. The enemy surrounds and attacks it, but it is impossible to take it." This sentence means that it is not able to achieve success for all aspects about an object when the object of study is large enough. Our education for the specialized higher technical college is of course a large enough object in today's education system. Therefore, it is necessary to discuss and study the education idea and education model for those institutes and students.

Especially, China has received great achievements in economics since more then 20 years. Some areas for example East-china has rapidly developed not only on industry, but also on others. The domestic and foreign markets need those graduates who learn in the institutes not only by theory reading, but also by practice -doing. This task should be finished by the people who work in polytechnic institutes. The problem is how to draw up a practical teaching program to train students who needs above demands.

This article will discuss the education idea for the specialized higher technical college from three aspects: international student exchange, practice training and record certificate reform.

\section{International Student Exchange}

The earth is becoming a small village. The International market needs the International graduates who know both or even more countries' cultures and technical standards[2]. The assistance they receive is regarded as a contribution to international understanding. 
About international student exchange, it has some resistances for the exchange program.

Traditionally student in foreign countries are quite free to shape their own courses of study. Although for many courses curricula are recommended and interim examinations are obligatory, in many other students are still free to choose between certain subjects and lectures[3].

The study fees in different countries are great different. In some countries the study is expensive, but in Germany even no study fees are charged .If neither the student nor their parents are able to pay for their living expenses the state helps. Under the Federal Education promotion Act (BAFoeG) students can obtain financial assistance. Half the amount is grant, the other half a loan which has to be repaid when the graduate enters a profession. Of course, the similar help method to the students exists also in other countries, including china.

Generally in the developed countries just under $60 \%$ of all students are at present accommodated hostels. About $40 \%$ of all freshmen are still living with their parents. Rents on the open market are a serious problem for many students. But at least there is a cheap insurance for students. In Germany, all are covered by the statutory accident insurance scheme and they are charge little for health insurance under the state scheme.

Another problem is the problem of student numbers. Despite considerable expansion of the university system the enormous growth in the number of people wanting to study has led to admission restrictions (numerous clauses) having to be introduced for some subjects in many developed countries and by a hostel in China. For the particularly attractive subjects such as medicine, dentistry and veterinary science there is a selection procedure which takes an account of the applicant's average high school graduation mark, and the time spent waiting for admission. There are also tests and interviews. Special consideration is given to hardship cases. In such courses as economics, law, industrial management and computer science available places are distributed. Every applicant is assigned to a particular university, where possible according is to choice.

All of above problems must be solved for international student exchange. Firstly, the teach-plan and the earned points of a student should be recognized from the universities where this student has studied. Secondly, the admission restrictions should be canceled. It is also necessary and extremely anxious for foreign students studying in Chinese institutes that the students quite free to shape their own courses of study in China.

\section{Practice Training}

The Chinese student teach-plan (including academic universities, similar institutions of high education and the specialized higher technical college) is in structure almost commonly. Table 1 illustrates the ratios of the teach-contents for a specialized subject of engineering science[4].

Through this teach-plan we can find that the effective practice hour are too less for students to train technical skills. Just $35.4 \%$ is not the real practice ratio .The course design, military training/labor and moral education reach the ratio $24.9 \%$. The read practice time is only $10.5 \%$ of the total teach-hours.

In addition, the quality of fieldwork (or multiple experiments), graduation project and experiment course is more and more difficult to control, because there are some problems in the practice system. For instance, the student numbers and laboratory numbers have not reached a common ratio. A Chinese idiom expresses this phenomenon: "Many monks and little congee". It means that the education supplies are less than education needs. To solve these problems, one of the effective methods is to use the resources of society including offices.

Enterprises, factories, etc....As students of education, they will be also interested to learn something of the research, working experience. The enterprises and factories need simultaneously the new physical strength to create new methods and change original ideas. Therefore, it is meaningful for both sides for practice course learning through using the resources of society. 
Tab. 1 Teach-hours Distribution for an Engineering Subject

\begin{tabular}{|c|c|c|c|c|c|c|c|c|}
\hline \multirow{2}{*}{\multicolumn{3}{|c|}{ Type of course }} & \multirow{4}{*}{$\begin{array}{l}\text { Credit } \\
59 \\
10 \\
\end{array}$} & \multirow{4}{*}{$\begin{array}{l}\text { Teach- } \\
\text { hour }\end{array}$} & \multicolumn{2}{|c|}{ Brief-summary } & \multicolumn{2}{|c|}{ Total-summary } \\
\hline & & & & & $\begin{array}{l}\begin{array}{l}\text { Teach-h } \\
\text { our }\end{array} \\
1115\end{array}$ & $\frac{\text { Ratio }}{51.5}$ & $\begin{array}{l}\text { Teach- } \\
\text { hour }\end{array}$ & Ratio \\
\hline \multirow{5}{*}{$\begin{array}{l}\text { Theory } \\
\text { Teach- } \\
\text { plan }\end{array}$} & \multirow{2}{*}{$\begin{array}{l}\text { Basic } \\
\text { foundation }\end{array}$} & Need & & & \multirow{2}{*}{1115} & \multirow{2}{*}{51.5} & \multirow{5}{*}{2167} & \multirow{5}{*}{64.6} \\
\hline & & select & & & & & & \\
\hline & $\begin{array}{l}\text { Subject } \\
\text { Foundation }\end{array}$ & Need & 37.5 & 564 & 564 & 26 & & \\
\hline & Subject course & Need & 8 & 128 & & & & \\
\hline & & Select & 22.5 & 360 & 488 & 22.5 & & \\
\hline & $\begin{array}{l}\text { Fieldwork (Mu } \\
\text { Experiments) }\end{array}$ & iple & 13 & 286 & 286 & 24.1 & & \\
\hline Practice & Course design & & 8 & 176 & 176 & 14.8 & & \\
\hline Teach- & Graduation proj & & 16 & 352 & 352 & 29.6 & 1188 & 35.4 \\
\hline plan & Experiment cou & & 8 & 254 & 254 & 21.4 & & \\
\hline & Military Trainir & $\mathrm{g} /$ Labor & 1 & 44 & 44 & 3.7 & & \\
\hline & Moral educatio & & 2 & 76 & 76 & 6.4 & & \\
\hline
\end{tabular}

\section{Record Certificate Reform}

Generally the record certificate for a student or an exchanged student includes subject area, catalogue number, description, class start date, class end date, attempted record, earned record, mark, grade, points, grading basis. Table 2 is the description of results of an exchanged student.

Tab. 2 Description of Results of an Exchanged Student

TERM: $\quad 0350 \quad$ UGRD Semester 22013

PROGRAM: EXUGD Exchange Enrolments Inbound UGRD

PLAN: $\quad$ EXCHINUGRD Exchange Undergrad Inbound Plan

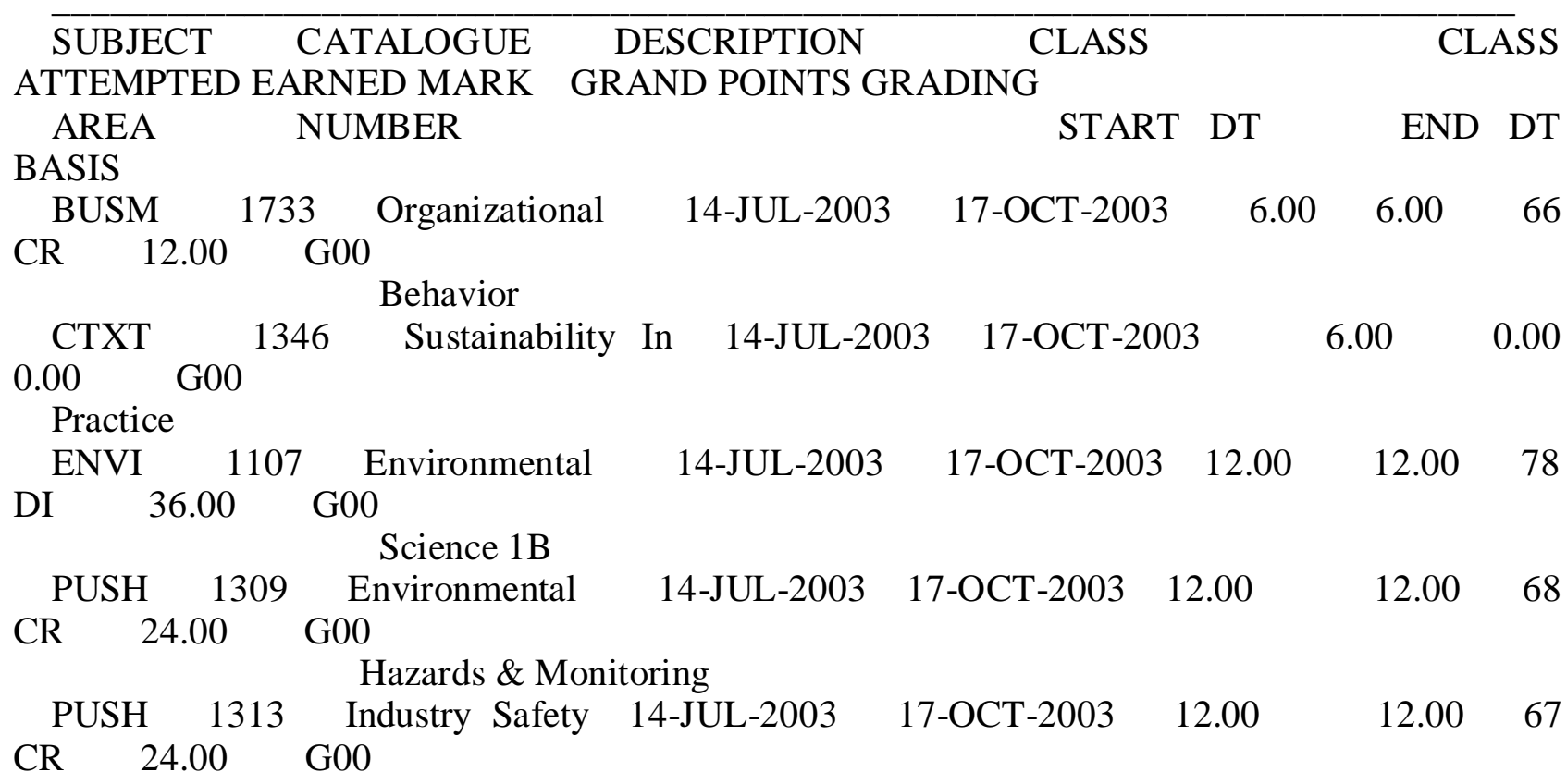


Total of term attempted

48.00

Total of term earned

Total of all term points

Undergraduate CAREER TOTALS

CUM GPA

CUM TOTALS

Total for Career attempted

Total for Career earned

Total for Career points
42.00

96.00

48.00

42.00

96.00

Through this certificate we can not understand what the course description mean. Only a course title is not much enough to express the contents of this course. For same courses the institutes have the same name, but the contents are different. For example, the course "Industry Safety" in RMIT University and in SIT Institute has so many different contents that we can consider it as another course. So, it is necessary to write the contents and details involved in a course.

In addition, the practice record certificate for the students in the specialized higher technical college has special sense. The practical record list should include more details instead of today only one number.

\section{Conclusion}

In Francis Bacons "Of Studies", we read ${ }^{[5]}$ : "They (Studies) perfect nature, and are perfected by experience. For natural abilities are like natural plants, that need pruning by study; and studies themselves do give forth directions too much at large, except they be bounded in by experience". Here, when we use practice program instead of experience to training and teaching our students, the teach-effect will better than with the pure theoretical program.

A major problem with this goal is that many teachers have not been trained in practice applications. Some of them find it even threatening to incorporate practice application as part of their teach-plan. A teacher-training project should be designed to help them to bridge the gap between theoretical teaching and practice teaching.

Although character education is a hot topic today in universities, it receives in manners often scant attention. For the specialized higher technical college or polytechnic institute, like SIT institute, it is difficult to point out the difference with other academic universities. The education model for successful practice application will be the eternal study topic in the future[6].

Generally, the international student exchange, practice training and record certificate reform are the practical approach on the education model for the specialized higher technical institute although a lot of details existing in the three aspects should be considered and designed.

\section{References}

[1] Mengzi. Mensius. Guangxi national press. 2003:133-135.

[2] Bernard J. Poole. Education for an Information Age. McGraw-Hill, Inc. 2012: 112-116.

[3] A. Hoffmann. Facts about Germany. Societets-Verlag. 2013: 213-232.

[4] SIT Deans Office. SIT Teach-plan for 2013 Credit System Management. Shanghai Institute of Technology. 2013:26-28.

[5] F. Bacons. Of Studies (from the article"The Chakra of Development Expertise: Perspectives of the Ex-advised as Advisors"). Exploring Education Development. 2012(4): 97-101.

[6] ZHANG Weijiang. Education Reform and Subject Building. Shanghai Jiaotong University Press. 2014:17-23. 